Bartın Üniversitesi

Eğitim Fakültesi Dergisi

Cilt 5, Sayı 3, s. 748-763, Ekim 2016

BARTIN - TÜRKIYE

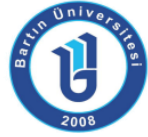

ISSN: 1308-7177
Bartin University

Journal of Faculty of Education

Volume 5, Issue 3, p. 748-763, October 2016

BARTIN - TURKEY

\title{
Kraliçe Arı Sendromu Bağlamında Kadın Öğretmenlerin Kadın Yöneticilere İlişkin Görüşleri
}

Gülşah IMAMOĞLU AKMAN, Öğretmen, Milli Eğitim Bakanlığı, ankaragulsah@gmail.com

Yener AKMAN, Öğretmen, Milli Eğitim Bakanlığı, yenerakman@yahoo.com

Öz: Bu araştırmanın amacı; Kraliçe Arı Sendromu bağlamında kadın öğretmenlerin kadın yöneticilerine ilişkin görüşlerinin belirlenmesidir. Bu çalışmada nitel araştırma yöntemi kullanılmıştır ve görüşme tekniği uygulanmıştır. Araştırmanın çalışma grubunu on dört kadın öğretmen oluşturmaktadır. Çalışmada katılımcıların görüşlerine göre üç ana tema saptanmıştır. Bu temalar; destek, yapı ve yetersizlik olarak belirlenmiştir. Destek teması altında, çoğu kadın öğretmen kadın yöneticilerin hem iş hem de aile ortamında desteklenmediklerini, iş ortamında güç çatışması yaşanacağını ve bir kısım öğretmen de sorunlarının daha kolay ifade edilebileceğini aktarmışlardır. Yapı teması altında, kadın yöneticilerin kıskanç, kaprisli, ayrıntıcı, kindar ve acımasız olduklarına yönelik olumsuz görüşlerle birlikte estetik ve sorumluluk sahibi olduklarına yönelik olumlu görüşler de belirtilmiştir. Son tema olan yeterlilik altında ise, kadın yöneticilerin tecrübesiz oldukları ve otorite sağlayamadıkları vurgulanmıştır. Ayrıca kadın öğretmenler kadın yöneticiler ile çalışmanın zor olduğunu ifade ederken, aynı ortamda birden fazla kadın yöneticinin olmasının örgütü olumsuz etkileyebileceğini söylemişlerdir. Araştırma sonucunda kadın yöneticilere yönelik olumsuz bir tutumun olduğu tespit edilmiştir. Bu doğrultuda kadın yöneticiler için rol model olabilecek kadın örneklerin sayısının artırılması ve liderlik eğitimi verilmesi önerilebilir.

Anahtar Kelimeler: Kraliçe arı sendromu, kadın öğretmen, kadın yönetici.

\section{The Opinions of Female Teachers about the Female Principals in the Context of the Queen Bee Syndrome}

\begin{abstract}
The aim of this study is to determine the opinions of female teachers about the female principals in the context of the queen bee syndrome. The qualitative research methods is used in tihis study and interview techniques were applied. The study group of research is comprised of fourteen female teachers. Three main themes were identified according to the views of the participants in the study. These themes are determined as support, temperament and sufficiency. Under the theme of support; most of female teacher reported that female principals haven't supported at work and family place and also there will be a power conflict between women workers and some teachers have transferred the problems can be expressed more easily. Under the theme temperament; there are negative opinions about female principals are expressed as jealous, capricious, detailed eye, vindictive, cruel and positive opinions as aesthetic and responsibility. Under the last theme of sufficiency; it is emphasized that female managers were inexperienced and not provide authority. In addition, female teachers have expressed that it is difficult to work with female managers and more than one woman principal in the same environment causes negative impact on the organization. As a result it was found that there is a negative attitude towards women managers.
\end{abstract}

Key Words: Queen bee syndrome, female teacher, female principal. 


\section{GíRiş}

Yirmi birinci yüzyılın son çeyreğinde kadın çalışanların işgücünün yaklaşık olarak yarısını oluşturmasına rağmen iş dünyasına katılımları noktasında önemli sorunlarla karşılaştıkları bilinmektedir (Lang, 2010). Halen kadın çalışanlar erkeklere göre daha az kazanç sağlamakta, kadınlara yönelik olumsuz tutumlar devam etmekte ve kadınların üst yönetici pozisyonlarına ulaşmaları daha zor olmaktadır (Carlson, Kacmar ve Whitten, 2006; Eurostat, 2009). Agars'a (2004) göre, yaygın cinsiyet kalıpları ve cinsiyet ayrımcılığı bu durumun altında yatan sebeplerden birisi olabilir. Kültürel yönden çoğu toplumda şefkat ve duyarlılık içeren toplumsal roller kadın cinsiyet rolleri içerisinde görülmektedir. Erkek rollerinde ise daha girişken, iddialı ve ısrarlı olma gibi daha eylemli davranışlar bulunmaktadır. Cinsiyet rolü ile uyuşmayan davranışlar sergileyen bireyler ise olumsuz değerlendirilme eğilimi ile karşılaşmaktadır (Eagly ve Karau, 2002). Schein'a (1975) göre bu uyumsuzluk kadın yöneticilerde sorun yaşamasına neden olabilir çünkü başarılı liderlik için gerekli özellikler daha çok erkek cinsiyet rolü ile ilişkili görülmektedir.

Çalışma hayatında, çoğu iş ortamı erkek egemen bir yapıya sahiptir. İ̧̧ adamı iş insanı ve bilim adamı da bilim insanı kavramlarıyla daha yeni yeni kabullenilmeye başlanmıştır. Ayrıca, kadınlara özgü çalışma stilleri üzerinde erkeklere özgü yaklaşımlar tercih edilmekte ve kadın rol model eksikliği hissedilmektedir (Bickford, 2011; Davey, 2008; Linehan ve Scullion, 2008). Kadın çalışanların üst yönetici pozisyonlarına gelmelerini engelleyen etmenler arasında Cam Tavan Sendromu (CTS) ve Kraliçe Arı Sendromu (KAS) sayılabilir. Virginia Woolf "Bir kadını, doktor, avukat, devlet memuru olmaktan alıkoyacak hiçbir şey olmadığı, tüm yolların açık olduğu zamanlarda bile, onun önüne çıkan pek çok engel ve hayalet olduğuna inanıyorum." biçiminde belirttiği düşünceleri de kadınların yükselmelerinde engellerin olduğunun altını çizmektedir (Adair, 2005).

Ancak, iş dünyasında kadınların diğer kadın çalışanlar ile olan ilişkileri tam olarak bilinmemektedir. Özellikle kadın yöneticilerin diğer kadın çalışanlar üzerindeki etkisi yeterince araştırılmamıştır. Araştırmalar, cinsiyet çeşitliliği ve yönetim kurulunda daha fazla kadın olan şirketlerin, daha az çeşitliliğe veya kadın yöneticisi olmayan şirketlere göre daha başarılı olduğunu göstermektedir (Herring, 2009; Joecks, Pull ve Vetter, 2012; Joy, Carter, Wagner ve Narayanan, 2007). Ancak kapsamlı bir araştırma, kadınların iş ortamında çok sayıda engelle yüz yüze olduğunu saptamıştır. Bu engeller sıklıkla kadınların işgücü katılımını, gelişimini ve yönetici pozisyonlarına gelmelerini engellemektedir. Bu engeller arasında yüksek rekabetçi iş ortamı (Niederle ve Vesterlund, 2007), uzun ve düzensiz çalışma saatleri (Goldin, 2014), iş-aile yaşamı dengesi (Groysberg ve Abrahams, 2014), düşük liderlik yeteneği ve duygusal istikrarsızlık algısı (Heilmann, 2001) belirtilebilir. Ayrıca Barsh ve Yee'ye (2012) göre kadın çalışanların karşılaştıkları engelleri gidermek için kültürel ve cinsiyet farkındalıkları tanımaya dönük çalışmalar ve uygulamalı liderlik ekipleri geliştirilebilir.

Avrupa Komisyonu'na (2015) göre, Avrupa'nın en büyük şirketlerinde üst düzey yönetici (CEO) olarak görev yapan kadınların oranı \% 3.6'dır. Amerika Birleşik Devletleri'nde (ABD) de benzer veriler olmakla beraber en büyük 500 şirket üzerine yapılan araştırmada kadın CEOların oranı \% 4.4 olarak saptanmıştır (Catalyst, 2015). Ekonomik Kalkınma ve Işsbirliği Örgütü (OECD) verilerine göre 2012 yılı itibariyle Türkiye'de kadın istihdamı \% 32.3 olurken OECD ülkeleri ortalaması ise \% 62.3 olarak saptanmıştır. Ayrıca, Türkiye İstatistik Kurumu (TÜiK) (2014) verilerine göre de 15 yaş ve daha yukarı yaş grubundaki kadın istihdamı 2004 yılında \% 23.3 iken 2014 yılında \% 30.3'e yükselmiştir. Üst düzey memur grubu istihdam oranları ise, 2011 yılında \% 8.7'den 2014 yılında \% 9'a ulaşmıştır. 2014 yılı itibariyle kadın milletvekili oranı \% 14 iken yerel yönetimlerdeki kadın belediye başkanlarının oranı ise \% 2.9 olarak belirlenmiştir. Milli Eğitim Bakanlığı (MEB) (2015) verileri açısından da kadın öğretmen 
sayısı (545.836) erkek öğretmen sayısından (447.958) fazla olmasına rağmen, kadın yönetici oranının yaklaşık \% 8 olduğu vurgulanmaktadır. Değinilen veriler incelendiğinde oransal olarak bir yükselme görülürken erkeklere göre kıyaslandığında, üst düzey pozisyonlarda görev yapan kadın çalışanların sayısının oldukça yetersiz olduğu değerlendirilebilir.

Alan yazında kadın çalışanların iş ortamında üst düzey pozisyonlara gelmeleri konusunda yapılan araştırmaların çelişkili sonuçlar içererek az sayıda olduğu görülmektedir. Bazı araştırmalara göre kadın yöneticiler, kadın çalışanları eşitlik ve başarıya ulaşmaları için teşvik ederken, bazılarında da kadın çalışanların fırsatlarını engellediği ve başarılarına karşı çalıştığına yönelik bulgular tespit edilmiştir. Çalışmalara göre yüksek statülü kadın yöneticilerin sayısındaki artış, cinsiyete dayalı ücret eşitsizliği azaltmaktadır. Ayrıca mevcut iş düzeyinde daha çok kadın çalışan varken, kadınların işten ayrılma eğilimlerinin düşük olduğu saptanmıştır. Dahası, kadınların oranlarının fazla olması, daha fazla kadın çalışanın terfi etmesine imkân sağlayabilir (Cohen ve Huffman, 2007; Elvira ve Cohen, 2001). Bu çalışmalarda özellikle üst düzey pozisyonlardaki kadınların, kadın çalışanların iş gücü çıktılarına olumlu etkide bulunduğuna yönelik sonuçlara ulaşıımıştır. Bazı çalışmalarda ise, kadın çalışanların diğer kadınlar üzerinde olumsuz bir etkiye sahip olduğu belirlenmiştir. Parks-Stamm, Heilman ve Hearns (2008), araştırmalarında, kadınların diğer kadınları kendilerini koruma açısından stratejik olarak cezalandırdıklarını tespit etmişlerdir. Ayrıca erkek egemen alanlarda üst düzey kadınlar, diğer kadınlar hakkında toplumsal cinsiyet kalıplarını teşvik ederken, iş ortamındaki cinsiyet arkadaşlığına mesafe koymaktadır. Ellemers, Van Den Heuvel, De Gilder, Maass ve Bonvini'ye (2004) göre de kadınların diğer kadınların kariyerlerinin zarar görmesinde asıl sorumlu olabileceğinin altı çizilmiştir. Ayrıca, daha kıdemli kadınların kendilerinden daha kıdemsizlere yönelik sert eleştirilerde bulundukları görülmektedir. Ellemers ve Barreto (2008), bu bulgular ışığında kendi benzersiz konumunu korumak isteyen ve diğer kadınlara eşit kariyer şansı tanımayan kadınların KAS içerisinde olduklarını belirtmektedir (akt. Ellemers, 2014). Benton (1980), kraliçe arı olarak otorite pozisyonunda olan kadınların, kraliçe durumunu korumak için diğer kadınların liderlik pozisyonlarından uzak durmaları için çaba gösterdiklerini aktarmaktadır. Ayrıca KAS ile yatay şiddet kavramı arasında ilişki olduğunu saptayan Ginn (1989), kraliçe arı fenomeninin iktidar gücü ile ilgili olduğunu vurgulamıştır.

KAS' da kadın yöneticiler daha erkeksi davranışlar içerisinde olabilir, fiziksel ve psikolojik olarak diğer kadın çalışanlarla arasına mesafe koyabilir ve mevcut cinsiyet hiyerarşisini meşrulaştırarak kendisini ifade edebilir (Derks, Laar ve Ellemers, 2016). Liderlik konumunu elde etmek isteyen kadınların izleyeceği en belirgin yol erkeksi özellikleri ve liderlik stillerini vurgulamaları olabilir. Çünkü başarılı liderler ve kadın rolleri hakkındaki kalıplaşmış düşünceler kadınların liderlik pozisyonlarına ulaşmaları için dezavantaj oluşturabilir (Eagly ve Karau, 2002; Heilman, 2001). Derks, Laar ve Ellemers'e (2016) göre, KAS iş yerinde cinsiyet eşitsizliğinin ana nedeni olmaktan ziyade cinsiyet ayrımcılığının sonucudur. Bu sendrom, öncelikli olarak kadınların kişiliklerinin ya da diğer kadınlara karşı doğal bir rekabetin tipik bir sonucu olarak görülmelidir ama erkek egemen iş ortamlarında olumsuz kalıplaşmış düşüncelerle tetiklenmektedir. Bu yargı, Tajfel ve Turner'a (1979) göre, bireylerin temel kimliklerinin cinsiyetlerinin bir parçası olduğunu açıklayan sosyal kimlik teorisine dayanmaktadır (akt. Derks, Laar ve Ellemers, 2016). Teoriye göre, dezavantajlı grubun üyeleri örgüt içerisinde azınlık durumunda kaldığında, kendi gruplarının tipik özelliklerini değersiz ya da kabul edilemez olarak algılayabilirler (Derks, Laar ve Ellemers, 2006). Bu durumda, kadın çalışanların kimlikleri tehdit altına girebilir. İ̧ ortamında cinsiyetçi davranışların genellikle erkeklerden geldiği varsayııı. Ancak son araştırmalar, erkek egemen ortamlarda başarılı olan kadınların kendi kadın astlarının ilerlemesinde ki olumsuzluk rolüne dikkati çekmektedir (Ellemers ve diğ., 2004). Derks, Ellemers, Laar ve Groot (2011), çalışmalara göre kadınlar tarafından ifade edilen cinsiyet üzerine olan önyargı kadınların iş yerindeki dezavantajlı konumuna güçlü bir meşruiyet 
sağlamaktadır. Bu durumda da başarılı kadınların kariyerlerinde ilerlemesi, altlarındaki kadınların ilerlemesini engelleyebilir.

Günümüzde hem dünyada hem de Türkiye'de kadın-erkek nüfus oranı ile kadın-erkek çalışanların istihdam ve üst düzey yönetici oranları göz önünde bulundurulduğunda aralarında bir dengesizlik olduğu dikkatleri çekmektedir. MEB verilerine göre de yönetici pozisyonunda bulunan kadın çalışanların oranı \% 8 olarak belirtilmektedir. Bu durum yönetim kademelerinde kadın temsiliyetinin oldukça düşük olduğunu göstermektedir. Bu konuda yapılan araştırmalar toplumsal önyargılar, kadınların kendi kendilerine koydukları engeller, kadın yöneticilerin hem cinslerine yönelik olumsuz tutumları gibi nedenlerle açıklanmaya çalışılmıştır. Alanyazın incelendiğinde, KAS'a yönelik çalışmalar avukatlar (Wiegand, 2015), öğretim üyeleri (Ellemers ve diğ, 2004), banka çalışanları (Johnson ve Mathur-Helm, 2011), polisler (Derks, Laar, Ellemers ve Raghoe, 2015) gibi çeşitli örneklemler üzerinde gerçekleştirilmiştir. KAS üzerine eğitim örgütlerinde yeterince çalışma yapılmadığı görülmektedir.

$\mathrm{Bu}$ araştırmanın amacı, MEB kamu ilköğretim okullarında görev yapan kadın öğretmenlerin KAS bağlamında görüşlerinin belirlenmesidir. Bu doğrultuda görüşme soruları kadın yönetici ve öğretmenlerin aralarındaki ilişkiyi görece tespit etmeye çalışmaktadır. Bu ilişkinin belirlenmesinin MEB'e bağlı okullarda kadın yöneticilerin ve öğretmenlerin sorunlarının kısmen de olsa saptanmasını sağlayacağı ve daha etkili politikaların oluşturulmasına hizmet edebileceği düşünülmektedir. Bu bağlamda, araştırmada aşağıdaki soruların cevapları aranmıştır:

1. Kadınların yönetim kademesinde olması hakkında ne düşünüyorsunuz?

2. Sizce kadın bir yönetici ile mi yoksa erkek bir yönetici ile mi çalışmak daha kolaydır? Neden?

3. Yöneticinizin erkek ya da kadın olması önemli midir? Neden?

4. Bir kurumda birden fazla kadın yöneticinin bulunması hakkında ne düşünüyorsunuz?

5. Sizce yöneticiniz kadın öğretmenleri yönetici olmaları konusunda destekler mi?

\section{YÖNTEM}

Çalışmanın yöntem bölümü; araştırma modeli, çalışma grubu, verilerin toplanması ve analizi başıkları ile sınıflandırılarak ayrıntııı açıklamalarda bulunulmuştur.

\subsection{Araştırma Modeli}

Bu çalışmada MEB kamu ilköğretim okullarında görev yapan kadın öğretmenlerin KAS bağlamında görüşlerinin belirlenmesi betimsel bir yaklaşımla ele alınmıştır. Çalışmada nitel araştırma yöntemlerinden fenomenolojik desen kullanılmıştır. Nitel araştırma, bireylerin davranışlarının altında yatan sebepleri keşfetmeye (Strauss ve Corbin, 1990) ve olayların ne şekilde anlamlandırdıklarına (Dey, 1993) yönelik bir süreç olarak ifade edilebilir. Fenomenoloji ise, bireylerin olgulara yönelik öznel düşüncelerini açığa çıkaran bir analiz deseni olarak belirtilebilir (Özdemir, 2010).

\section{2. Çalışma Grubu}

Bu araştırmanın çalışma grubunu 2014-2015 eğitim öğretim yılında Ankara ili Altındağ ilçesinde kamu ilköğretim okullarında görev yapmakta olan on dört kadın öğretmen oluşturmaktadır. Araştırma verileri görüşme tekniği ile toplanmıştır. Greasley ve Ashworth'e (2007) göre, görüşme tekniğinde, bireyin karşılaştığı olayları nasıl anlamlandırdıkları ve değerlendirdikleri saptanmaya çalışılmaktadır. Araştırmada belirlenen on beş kadın öğretmenden on dördü gönüllü olarak çalışma grubuna katılmıştır. Bir öğretmen ile gerçekleştirilen görüşme ise teknik sebeplerden dolayı tamamlanamamıştır. Çalışma grubu belirlenirken Patton'un (1987), sınıflandırmasına göre amaçlı örneklem yöntemlerinden ölçüt 
örneklemesi kullanılmıştır (akt. Yıldııım ve Şimşek, 2005). Ölçüt örnekleme yönteminde, “... temel anlayış önceden belirlenmiş bir dizi ölçütü karşılayan bütün durumların çalışılmasıdır. Burada sözü edilen ölçüt veya ölçütler araştırmacı tarafından oluşturulabilir ..." biçiminde ifade edilebilir (Yıldırım ve Şimşek, 2005). Bu doğrultuda öğretmenlerin en az on yıl öğretmenlik kıdemine sahip olmalarına dikkat edilmiştir. Çalışma 2015-2016 eğitim-öğretim yılının Nisan ve Mayıs aylarında gerçekleştirilmiştir. Çalışma grubuna yönelik betimsel bilgiler Tablo 1'de verilmiştir:

Tablo 1

Çalışma Grubunun Betimsel Özellikleri

\begin{tabular}{lccc}
\hline Kod & Mesleki kıdem & Branş & Okul türü \\
\hline Ö1 & $25 \mathrm{yıl}$ & Sosyal bilgiler & Ortaokul \\
Ö2 & $10 \mathrm{yıl}$ & Rehberlik & Ortaokul \\
Ö3 & $23 \mathrm{yıl}$ & Teknoloji-Tasarım & Ortaokul \\
Ö4 & İngilizce & Ortaokul \\
Ö5 & $10 \mathrm{yll}$ & Türkçe & Ortaokul \\
Ö6 & $20 \mathrm{yll}$ & Ortaokul \\
Ö7 & $22 \mathrm{yll}$ & Ilköğretim matematik & Ortaokul \\
Ö8 & $25 \mathrm{yıl}$ & Fen ve teknoloji & Illkokul \\
Ö9 & $24 \mathrm{yıl}$ & Sınıf & Ortaokul \\
Ö10 & $15 \mathrm{yll}$ & Görsel sanatlar & Ortaokul \\
Ö11 & $20 \mathrm{yll}$ & Teknoloji-Tasarım & İlkokul \\
Ö12 & $24 \mathrm{yll}$ & Sınıf & İlkokul \\
Ö13 & $37 \mathrm{yll}$ & Sınıf & İlkokul \\
Ö14 & $36 \mathrm{yll}$ & Sınıf & İlkokul \\
\hline
\end{tabular}

Tablo 1'e göre katılımcıların 5'i (\% 35.7) ilkokulda ve 9'u (\% 64.3) ortaokulda görev yapmaktadır. Diğer yandan katılımcıların 4'ünün 10-20 yıl (\% 28.5) ve 10'unun 21-30 yıl (\% 71.5) mesleki kıdeme sahip olduğu görülmüştür.

\section{2. İşlem}

Görüşme formu oluşturulurken öğretmenlerin KAS çerçevesinde kadın yöneticileri ile aralarındaki ilişkiye yönelik düşüncelerin saptanması amacıyla alan yazın incelemesi yapılmıştır. Görüşme soruları genel olarak kadın yöneticilerin varlığı, yöneticilikte cinsiyetin önemi, yönetici-öğretmen ilişkisi (eleştiri, destek), kadın yöneticilerin karakteri ve yeterlilikleri konularında irdelemeye ilişkin hazırlanmıştır. Araştırma verileri yarı-yapılandırıımış bir form ile elde edilmiştir. Öncelikli olarak iki yönetici ve iki öğretmen ile alan yazına dayalı olarak oluşturulan taslak form üzerinde görüşülmüş ardından bir alan uzmanının görüşleri doğrultusunda görüşme formu soruları hazırlanmıştır. Son olarak formda anlam bozukluklarını gidermek amacıyla iki Türkçe öğretmeninin görüşleri alınmış ve taslak form son haline getirilmiştir. Görüşme yapılacak katılımcılarla önceden iletişime geçilmiş, araştırmanın amacına yönelik bilgiler verilmiş ve kendi istekleri doğrultusunda uygun zamanda görüşmeler yapılmıştır. Bazı görüşmelerde veri kaybına sebep olmamak için katılımcıların izni doğrultusunda ses kaydı tutulmuştur. Ses kaydı yapılan görüşmeler ortalama 25-30 dakika sürmüştür. Bazı görüşmelerde de ortalama 50 dakika süren yazılı kayıt tutulmuştur. Görüşme sırasında bazı katılımcılara yarı-yapılandırılmış form sorularına ek olarak sondaj sorularda yöneltilmiştir. Görüşmeler tamamlandığında hem ses kayıtları hem de yazılı kayıtların doğruluğu katılımcılar tarafından teyit edilmiştir.

Araştırma verilerinin çözümlenmesi betimsel analiz ile gerçekleştirilmiştir. Yıldırım ve Şimşek'e (2005) göre, betimsel analizde, "elde edilen veriler, daha önceden belirlenen temalara göre özetlenir ve yorumlanır. Görüşülen ya da gözlenen bireylerin görüşlerini çarpıcı 
bir biçimde yansıtmak amacıyla doğrudan alıntılara sık sık yer verilir" biçiminde ifade edilmektedir. Analiz sürecinde ilk olarak, yazılı ve ses kaydı olarak elde edilen veriler bilgisayar ortamına metin olarak aktarılmıştır. Ardından veriler çağrışım yaptıkları konulara göre sınıflandırılmıştır. Görüşme formu çerçevesinde belirlenen temalar doğrultusunda benzer veriler bir araya getirilmiştir. Ayrıca katılımcı görüşleri doğrudan alıntı ile raporlanmıştır. Öğretmenler Ö1, Ö2... olarak kodlanmış şekilde sunulmuştur. Son olarak işlenen veriler sayısallaştırılarak frekans ve yüzdeleri hesaplanıp ifade edilmiştir.

Nitel araştırmaların en önemli özelliklerinden birisi olarak inandırıcılık kavramı belirtilebilir. Inandırıcılı̆ı sağlamanın yolları olarak ise geçerlik ve güvenirlik kavramları üzerinde durulmaktadır. Nitel araştırmalarda geçerlik, araştırılan konunun olduğu gibi ele alınıp, tarafsız olarak gözlenmesi olarak nitelendirilebilir. Yıldırım ve Şimşek (2005), elde edilen verilerin ayrıntılı olarak raporlaştırılmasının ve doğrudan alıntılara yer verilmesinin geçerlik için çok önemli bir ölçüt olduğunu aktarmıştır. Araştırmanın güvenirliğini sağlamak için veriler farklı bir uzman tarafından da değerlendirilmiştir. Veriler tekrar analiz edilmiş ve veriler temalar altında tekrar sınıflandırılmıştır. Miles ve Huberman'ın (1994) formülü [Güvenirlik= Görüş Birliği / (Görüş Birliği + Görüş Ayrılığı) x 100] aracılığıyla güvenirlik .90 olarak saptanmıştır. Bu durumda görüş ayrılığı .10 olarak hesaplanmıştır. Yıldırım ve Şimşek'e (2005) göre, güvenirlik oranının \% 70 ve üzerinde olması çalışmanın güvenilir bir araştırma olduğunu göstermektedir.

\section{BULGULAR}

Araştırma sonucunda ulaşılan verilere dayalı olarak kadın öğretmenlerin görüşleri destek, yapı (mizaç, karakter) ve yeterlilik temalarına göre analiz edilmiştir. Kadın öğretmenlerin algıları değinilen temalara göre sınıflandırılmış ve aşağıda sunulmuştur.

Kadın öğretmenlerin destek temasına ilişkin bulgular Tablo 2'de sunulmuştur:

Tablo 2

Kadın Öğretmenlerin Destek Temasına Iliş̧kin Algıları

\begin{tabular}{llcc}
\hline & Temalar & $\boldsymbol{f}$ & $\mathbf{\%}$ \\
\hline 1 & Arkadaşlarını kayırırlar. & 4 & 25 \\
2 & Birden fazla kadın yönetici varsa güç çatışması yaşanır. & 4 & 25 \\
3 & Sorunlar daha kolay ifade edilir. & 3 & 18.7 \\
4 & Empati sahibidir, sorunları anlar. & 1 & 6.2 \\
5 & Ailede de okulda da destek verilmez. & 1 & 6.2 \\
6 & Birden fazla kadın yönetici varsa acemice bir yarış içerisine girerler. & 1 & 6.2 \\
7 & Empati kuramazlar. & 1 & 6.2 \\
8 & Kadın kadının kuyusunu kazar. & 1 & 6.2 \\
\hline
\end{tabular}

Tablo 2'de görüldüğü üzere, destek teması altında, kadın öğretmenler okulda birden fazla kadın yönetici olduğunda bu durumun güç çatışmasına neden olabileceğini aktarmışlardır. Bu doğrultuda, katılımcı Ö6 "... okulda kadın-erkek yönetici sayısında bir denge olmalıdır. Eğer kadın yönetici sayısı birden fazla olursa, aralarında sorunlar, güç çatışmaları yaşanabilir" şeklinde görüşünü belirtmiştir. Ayrıca bazı öğretmenlerin ifadelerinden de kadın yöneticilerin daha samimi oldukları arkadaşlarına yönelik pozitif ayrımcılık sergileyeceklerine yönelik bir algılarının bulunduğu da anlaşılmaktadır. Bu bağlamda, bir katılımcı (Ö1) "... çevrelerinde kendilerine yakın olan, yakın ilişki içerisinde olduklarına yük gerektiren işleri vermezler." Ek olarak bazı öğretmenler, sorunlarını daha kolay aktarabilmelerinde yardımcı olduklarını ifade etmektedir. Bu görüşü destekleyen katılımcı Ö2, “... ben erkek idareciler ile mesafeliyim, bayanlarla daha rahat iletişim kurabiliyorum" ve katılımcı Ö10, "bayan öğretmeni bayan idareci daha iyi anlar, duvardan düşeni duvardan düşen anlar..." şeklinde düşüncelerini belirtmişlerdir. Ayrıca katılımcı Ö1, "... bir erkek gibi her işi yüklenebilecek yeterlilikte görülmüyor, okul idaresi de ev de yeterince destek vermiyor" ve "... erkekler daha politik 
yaklaşıyor, kadın idareciler ise acemice rekabet içerisine giriyor." olarak düşüncelerini aktarmıştır. Destek teması incelenecek olursa öncelikli olarak göze çarpan nokta olumsuz (\% 75) olarak nitelendirilebilecek görüşlerin yüksek olmasıdır. Ayrıca, kadın yöneticilerin hem okulda hem evlerinde yeterince destek görmediği, çeşitli politik becerileri tam olarak sergileyemedikleri ve aynı ortamda kadın yönetici sayısının fazla olmasının örgütü olumsuz etkileyebilecek durumların yaşanmasına neden olabileceği belirtilebilir.

Kadın öğretmenlerin yapı temasına ilişkin bulgular Tablo 3'te sunulmuştur:

Tablo 3

Kadın Öğretmenlerin Yapı Temasına Ilişkin Algıları

\begin{tabular}{lllc}
\hline & Temalar & $f$ & $\%$ \\
\hline 1 & Kıskançlık ve çekememezlik vardır. & 6 & 18.7 \\
2 & Kaprisli ve duygusaldır. & 5 & 15.6 \\
3 & Ayrıntıcıdır. & 4 & 12.5 \\
4 & Kindar ve acımasızdır. & 12.5 \\
5 & Önyargılıdır. & 4 & 9.3 \\
6 & Sorumluluk sahibidir. & 3 & 6.2 \\
7 & Dedikoducudur. & 2 & 6.2 \\
8 & Olayları kişiselleştirir. & 2 & 6.2 \\
9 & Ukala bir tavır gösterir. & 2 & 3.1 \\
10 & Yüreklerinde olan düşünceler hep ağızlarındadır. & 1 & 3.1 \\
11 & Kadınlar estetiktir, ortamı güzelleştirir. & 1 & 3.1 \\
12 & Bencildir. & 1 & 3.1 \\
\hline
\end{tabular}

Tablo 3 incelendiğinde, yapı teması altında, kadın öğretmenlerin kadın yöneticiler hakkındaki algıları büyük oranda olumsuz olarak nitelendirilebilecek yaklaşımlar içermektedir. "Sorumluluk sahibidir" ve "Kadınlar estetiktir, ortamı güzelleştirir" ifadeleri dışındaki olumsuz yaklaşımların oranı \% 90.7 olarak saptanmıştır. En yüksek frekansa sahip ifadeler olarak kıskançlık, çekememezlik, kaprisli olma, aşırı duygusallık, ayrıntılara takılma, kindar, acımasız ve önyargıı olma belirtilebilir. Bu doğrultuda, katılımcı Ö3, "... kıskançık olmaz mı? Tek olmak isterler her yerde..." şeklinde görüşlerini aktarmıştır. Destekler nitelikte bir katılımcı (Ö6) da, "...kadınlar daha kıskanç olmaları sebebiyle dezavantaj yaşayabilir" demiştir. Katılımcı Ö1 ise, "... kadınlar kaprisli ve daha duygusal yaklaştıkları için sorunları çözme noktasında bazen yetersiz kalıyorlar" biçiminde düşüncelerini ifade etmişlerdir. Ek olarak katılımcı Ö5, "... kadınlar çok acımasız ve kindar olabiliyorlar birbirlerine karşı", ayrıca bir katılımcı (Ö6), "... eski okulumda, benim hazırladığım tören programını toplantıda herkesin içinde üzerlerini çizerek değiştirmişti. Çok ağırımı gitti” olarak belirttiği görüşü ile kadın yöneticilerin kin tutma ve ayrıntıcı olma konusuna dikkat çekmektedir. Katılımcı Ö3 ise olumlu bir görüş olarak kadın yöneticilerin bulundukları ortama farklı bir bakış açısıyla yaklaşarak "... kadınlar her şeye estetik açıdan yaklaşır ve ortamı güzelleştirir" biçiminde görüşünü ifade etmiştir. Kadın yöneticilere olumlu yönde yaklaşan katılımcı Ö9 da, "... bayanlarda göreve sorumluluk daha fazladır" olarak düşüncelerini aktarmıştır.

Kadın öğretmenlerin yeterlilik temasına ilişkin bulgular Tablo 4'te sunulmuştur: 
Tablo 4

Kadın Öğretmenlerin Yeterlilik Temasına ilişkin Algıları

\begin{tabular}{llcc}
\hline & Temalar & $\boldsymbol{f}$ & $\mathbf{\%}$ \\
\hline 1 & Tecrübesizdir. & 5 & 35.7 \\
2 & Mantık, duygularının gerisinde kalır. & 2 & 14.2 \\
3 & Otorite sağlayamaz. & 2 & 14.2 \\
4 & Erkeklerle aynı yeterlilikte değildir. & 1 & 7.1 \\
5 & işinin ehli değildir. & 1 & 7.1 \\
6 & Planlı programlı değiller. & 1 & 7.1 \\
7 & Sorun çözemezler. & 1 & 7.1 \\
8 & Politik becerileri zayıftır. & 1 & 7.1 \\
\hline
\end{tabular}

Tablo 4'e göre, yeterlilik teması altında, kadın yöneticilerin yeterlilik temasındaki görüşler incelendiğinde olumsuz ifadeler dikkat çekmektedir. Katılımcı Ö5, “... belki de kadınlarda yüzlerce yıllık bir yöneticilik eksikliği var. Erkekler yıllardır yönetici, kadınlar tecrübe edinmeli". Destekler nitelikte, katılımcı Ö6, "... erkek idareciler daha tecrübeli, kadınlarda bu işi öğrenmelidirler" olarak düşüncelerini ifade etmişlerdir. Ayrıca, katılımcı Ö1, kadın yöneticilerin zaman zaman mantıklı kararlar almadıklarını belirtip "... duygusal yaklaşıyorlar. Mantık, duygularının gerisinde kalıyor" biçiminde görüşlerini aktarmıştır. Katılımcı Ö1 de, otorite konusunda sorun yaşadıklarına değinip, “... otorite sağlamada maalesef erkek idareciler, kadınlardan daha etkin gibi görünüyor" ve katılımcı Ö6 da, "... erkek idareci olması avantajdır, okullarda disiplin ve otorite olur" olarak bu görüşü desteklemektedir.

Kadın öğretmenlerin yönetici cinsiyetinin çalışma ortamına etkisine ilişkin bulguları Tablo 5'te sunulmuştur:

Tablo 5

Kadın Öğretmenlerin Yönetici Cinsiyetinin Çalışma Ortamına Etkisine Ilişkin Algıları

\begin{tabular}{llcc}
\hline & Temalar & $\boldsymbol{f}$ & $\%$ \\
\hline 1 & Erkek yöneticiler ile çalışmak daha kolay & 7 & 50 \\
2 & Kadın yöneticiler ile çalışmak daha kolay & 1 & 7.1 \\
3 & Cinsiyet yönünden bir farklılık yoktur. & 6 & 42.8 \\
\hline
\end{tabular}

Tablo 5'de görüldüğü üzere, kadın öğretmenlerin yedisi (\% 50) erkek yöneticiler; biri (\% 7.1) ise kadın yöneticiler ile çalışma daha kolay olduğunu belirtirken, altısı (\% 42.8) da yöneticinin cinsiyeti noktasında bir farklılık olmadığı ifade etmiştir. Bu doğrultuda, katılımcı Ö9, "... erkek yönetici ile çalışmayı isterim. Erkekler daha candan davranıyor. Kadınlar ise birbirinin kuyusunu kazıyor", katılımcı Ö12 ise, "... çekişme olacağını düşünüyorum, o yüzden bayan yönetici ile çalışmak istemem". Katılımcı Ö2 de, kadınlarla çalışmanın daha kolay olduğunu belirtip, "... daha yakın hissediyorum, kendimi daha rahat ifade edebiliyorum" olarak görüşünü aktarmıştır. Cinsiyet yönünden bir farklııı olmadığını söyleyen Ö13 ise "... fark etmez, yeter ki işini yapsın, adaletli olsun..." ve Ö14 de, "önemli olan işini yapabiliyor mu? Gerisi önemli değil..." biçiminde düşüncelerini ifade etmiştir.

Kadın öğretmenlerin yönetici cinsiyetinin önemine ilişkin bulguları Tablo 6'te sunulmuştur:

Tablo 6

Kadın Öğretmenlerin Yönetici Cinsiyetinin Önemine Ilişskin Algıları

\begin{tabular}{llcc}
\hline & Temalar & $f$ & $\%$ \\
\hline 1 & Önemlidir & 2 & 14.2 \\
2 & Önemsizdir & 12 & 85.8 \\
\hline
\end{tabular}


Tablo 6'dan izlenebileceği gibi, kadın öğretmenlerin çalıştıkları yöneticilerinin cinsiyetlerine yönelik algılarında iki katılımcı cinsiyet tercihinde bulunarak önemli olduğunu (\% 14.2) belirtirken on iki katılımcı cinsiyetin yönetim kademesinde önemsiz (\% 85.8) olduğunu ifade etmiştir. Bir katılımcı (Ö7), "... benim için önemlidir ve erkek yönetici ile çalışmak isterim. Erkekler olaylara daha nesnel yaklaşıyor..." olarak görüşlerini dile getirmiştir. Yönetimde cinsiyetin önemsiz olduğuna değinen katılımcı Ö1, “... önemli değildir, dikkat ettiğim nokta bilgili ve kişilikli olmasıdır" şeklinde; katılımcı Ö5 ise, "... kadın olmasını isterim. Kadınların artık iş gücünde söz sahibi olması lazım" ve katılımcı Ö7 de, "... anlayışlı olsun, adaletli olsun yeter, cinsiyetin önemli yok..." olarak düşüncelerini aktarmışlardır.

Kadın öğretmenlerin çalışma ortamında kadın yönetici sayısının birden fazla olmasına ilişkin bulguları Tablo 7'de sunulmuştur.

Tablo 7

Kadın Öğretmenlerin Çalışma Ortamında Kadın Yönetici Sayısının Birden Fazla Olmasına Iilişkin Algıları

\begin{tabular}{llcc}
\hline & Temalar & $\boldsymbol{f}$ & $\%$ \\
\hline 1 & Olumludur & 1 & 7.1 \\
2 & Olumsuzdur & 11 & 78.5 \\
3 & Fark etmez & 2 & 14.2 \\
\hline
\end{tabular}

Tablo 7'de görüldüğü üzere, çalışma ortamında kadın yönetici sayısının birden fazla olmasının olumlu yansımaları olacağını belirten bir katılımcı (\% 7.1) bulunmaktadır. Bu doğrultuda katılımcı Ö3, “... kadın yöneticiler detaylarla ilgilenirler ama sorun oluşturacağını zannetmiyorum" olarak görüşünü ifade etmiştir. Katılımcıların çoğunluğu ise bu durumun olumsuz (\% 78.5) sonuçlar doğurabileceğinin altını çizmiştir. Destekler nitelikte, katılımcı Ö14, "... ben kendi işime bakarım kadın erkek fark etmez", katılımcı Ö4, "... kaos olurdu, iki kişi fazla..." ve katılımcı Ö6 ise, "... olmamalı, kadınlar arasında güç çatışması yaşanabilir" şeklinde düşüncelerini belirtmişlerdir. Ayrıca katılımcı Ö13 ise birden fazla kadın yöneticinin olumlu ya da olumsuz bir etkisi olmayacağını aktarıp, "... aynı anda çalışabilirler, bu durum çalışanların huyu ile ilgilidir" şeklinde görüşünü dile getirmiştir.

\section{SONUÇ, TARTIŞMA VE ÖNERILER}

Bu araştırmada MEB kamu ilköğretim okullarında görev yapan kadın öğretmenlerin KAS bağlamında kadın yöneticilerine yönelik görüşlerinin belirlenmesi amaçlanmaktadır. Araştırmada kadın öğretmenlerin görüşlerinin üç ana tema altında toplandığı tespit edilmiştir.

Bu temalardan ilki destek teması olarak belirlenmiştir. Destek teması altındaki görüşler incelendiğinde kadın öğretmenlerin görüşlerinin büyük oranda olumsuz olduğu aktarılabilir. Olumsuz görüşler arasında kadın yöneticiler arasında güç çatışması yaşanacağı ve bir yarış ortamı içerisine girileceği belirtilmektedir. Destekler nitelikte Bickford (2011) da yapmış olduğu KAS yaşayan yönetici tanımında yöneticilerin hem cinslerinin kuyusunu kazabileceğine değinmiştir. Ayrıca araştırma bulgularına göre iş ortamında kadın yöneticilerin hem diğer yöneticilerden hem de özel hayatlarında ailelerinden yeterince destek alamadığı saptanmıştır. iş ortamında ve aile yaşantısında yeterince destek görememenin altında yatan sebeplerden birisi olarak kadınlara atfedilen toplumsal rolleri ve kişilik özellikle çerçevesindeki yaklaşım belirtilebilir. Bu doğrultuda Niederle ve Vesterlund'un (2007) çalışmasına göre, iş ortamında kadınlar yarış ve rekabet içerisinde bulunmaktan hoşlanmamaktadır. Bu ruh halinin sonucu olarak da üst pozisyonlara gelme ihtimalleri daha düşük olabileceği ifade edilmiştir. Mukherji de (2010), yöneticiliğin bir erkek mesleği olarak görüldüğünü belirtmektedir. Erkeklerin kişilik özelliklerinde bulunan iddialı, hırslı ve sert olma gibi özellikler (Prentice ve Carranza, 2002) ise tarihsel bağlamda yöneticilik mesleği ile bağdaştırılmıştır. Bu açıdan konuya yaklaşıldığında kadınlara atfedilen toplumsal roller ile yöneticilik mesleği ile bağlantılı özellikler tam olarak 
örtüşmemektedir. Bu durum gerek iş gerekse aile ortamında kadınların yöneticilik konusunda yeterince destek alamamasının sebeplerinden birisi olabilir. Ek olarak, Morrison ve Von Glinov (1990) da, desteksizliği CTS'ye sebep olan önemli örgütsel engellerden birisi olarak vurgulamaktadır. Ayrıca araştırmadan kadın yöneticilerin kadın çalışanlara yönelik pozitif ayrımcılık yapabileceğini belirten görüşler de elde edilmiştir. Bu durumu olumlu görüşlerle beraber irdelediğimizde kadın yöneticiler hem cinslerinin özel durumlarını anlama konusunda empati kurabilir, sorunların çözümünde yardımcı olabilir ve gerekirse kayırıcı bir tutum da gösterebilir. Destekler nitelikte, iş ortamında kadın çalışanların sayısının fazlalığının kadınların işten ayrılma oranlarını düşürdüğü (Cohen ve Huffman, 2007) ve terfi oranlarını yükseltebileceği (Elvira ve Cohen, 2001) çeşitli araştırmalarda tespit edilmiştir.

Araştırmanın ikinci teması ise yapı (mizaç-karakter) temasıdır. Bu tema altında ifade edilen görüşler incelendiğinde kadın çalışanlar kadın yöneticilere yüksek oranda olumsuz davranış ve özellikler atfetmiştir. Bunlar arasında kıskançlık, çekememezlik, kaprisli, olumsuz açıdan duygusal ve önyargılı olma, kindarlık, acımasızlık, dedikodu yapmak ve bencillik göstermek sayılabilir. Ancak bazı kadın öğretmenler kadın yöneticilerin sorumluluk sahibi olduğunu ve sorunlara karşı estetik bir yaklaşım sergilediklerini de belirtmişlerdir. Araştırma bulguları ile uyumlu olarak Özçelik (2008), kadınların daha duygusal bir yapıya sahip olduğunu belirterek, olayları duygusal açıdan yorumlayıp, kişiselleştirebildiklerini ve iş ortamının olumsuz etkileyebileceğini vurgulamıştır. Ayrıca Arslan'a (2008) göre de, kadınlar üzerine gerçekleştirilen bir çalışmada; kadınların iş dışı sorunlar çıkardığı, dedikodu yaptıkları ve birbirlerini daha çok şikayet ettikleri tespit edilmiştir. Ek olarak kadın yönetici olarak erkek egemen bir çalışma ortamında ayakta durabilmek daha çok çalışmayı da beraberinde getirmektedir (Zenger ve Folkman, 2012). Yoğun çalışma temposu ve yüksek performans kaygısı yapı olarak daha hassas olan kadın yöneticilerin çalışma arkadaşlarına aşırı yüklenmelerine sebep olabilir. Bu durum da kadın yöneticilerin daha acımasız bir tutum içerisinde olabileceği şekilde yorumlanabilir (Özçelik, 2008). Zaten Gökakın'ın (2000) araştırmasına göre de, kadın yöneticiler ile çalışanların stres düzeyinin daha yüksek olduğu belirlenmiştir. Ayrıca, Çelikten (2004), araştırmasında kadın öğretmenler ve yöneticiler arasında kıskançlık hissinin bulunduğunu saptamıştır.

Araştırmanın üçüncü teması olarak yeterlilik teması belirlenmiştir. Yeterlilik teması altında görülen ifadelere göre kadın çalışanlar kadın yöneticilerin tecrübesiz olduklarını, kararlarında duygusallığın ön planda olduğunu ve otorite sağlayamadıklarını aktarmışlardır. Asında kadın çalışanların kadın yöneticiler yeterliliği hakkındaki olumsuz düşüncelerinin sebeplerden birisi olarak kadın yöneticilerin kendi kişiliklerine özgü bir yönetim yaklaşımı geliştirememiş olmalarından kaynaklanabilir. Tarihsel açısından yöneticilik mesleğinin erkeklerle özdeşleştirildiği düşünüldüğünde, kadın yöneticiler de erkek yöneticilerin bazı özelliklerini benimseyerek yönetim anlayışlarını erkeksi bir perspektif çerçevesinde geliştirdiği belirtilebilir. Bu durum ise, Annis'e (1995) göre, "erkek gibi lider" yaklaşımına yol açmıştır. Mevcut araştırmanın bulguları incelendiğinde katılımcılar, kadınlar için yeterince tecrübe sahibi olmadıklarını ve kadın rol model bulunmadığını ifade etmişlerdir. Kadınların iş yaşamına aktif olarak katılma süresi ve oranı göz önünde bulundurulduğunda kadın yönetici sayısının az olması olası görülebilir. Bu durum da kadın yöneticilerin erkeklere göre daha tecrübesiz olabileceği şeklinde yorumlanabilir (Özçelik, 2008). Zel'e (2002) göre, Amerikan Yönetim Topluluğu üyelerinin üzerinde yapılan bir araştırmada da kadın yöneticilerin; akıl hocası olmaması (\% 65), görüş yetersizliği (\% 50) ve oyunun nasıl oynanacağını bilmemek (\% 38) gibi sorunları oldukları tespit edilmiştir. Bu sorunlar hem sayısal hem de nitelik yönünden örnek olabilecek kadın yönetici yetersizliğine vurgu yapmaktadır. Ayrıca Gökakın (2000), özellikle genç kadın yöneticilerin daha yumuşak bir yapıya sahip olduklarından, çalışanların bazı 
isteklerini geri çevirirken zorluk yaşadıklarını ve sonucunda otorite kurma noktasında sıkıntı yaşayabildiklerini belirtmiştir.

Ayrıca araştırma bulgularına göre çalışma ortamında kadın öğretmenlerin \% 85.8'i yöneticinin cinsiyetinin önemli olmadı̆̆ını belirtmiştir. Ancak katılımcıların \% 50'si erkek yöneticiler, \% 7.1'i ise kadın yöneticiler ile çalışmanın daha kolay olduğunu eklemişlerdir. Ayrıca katılımcıların \% 78.5' $\mathrm{i}$ iş ortamında birden fazla kadın yöneticinin bulunmasının ortamı olumsuz etkileyeceğini aktarmışlardır. Bickford'un (2011) araştırmasına göre de kadınların çoğunluğu erkek yöneticiler ile çalışma eğilimindedir. Bunun sebebi olarak da erkeklerin isteklerini daha açık ifade etmeleri gösterilmiştir. Bir başka araştırmada da kadın yöneticiler ile çalışan kadınların erkek yöneticiler ile çalışanlara göre daha fazla sağlık sorunları yaşadıkları saptanmıştır. Destekler nitelikte Randstad'ın araştırması da, kadın çalışanların \% 54'ünün erkeklerle, \% 29'unun ise kadınlarla çalışmak istediklerini göstermektedir. Bu araştırmalarla uyumlu olarak Çelikten (2004) de, kadın öğretmenlerin erkek yöneticiler ile çalışmayı tercih ettiklerini tespit etmiştir. Değinilen araştırmaların tersine, Sertkaya, Onay ve Ekmekçi (2013), spor örgütlerinde yapmış oldukları araştırmaları ise kadın çalışanların hemcinslerinin yönetici konumunda olmalarını daha çok tercih ettiklerini göstermektedir. Ayrıca Cortis ve Cassar (2005) da, kadın çalışanların kadın yöneticilere yönelik daha olumlu düşüncelere sahip olduklarını belirlemiştir.

Son söz olarak, araştırma bulguları göz önünde bulundurulduğunda belirlenen destek, yapı ve yeterlilik temalarının tümünde kadın öğretmenler kadın yöneticilere yönelik ağırlıklı olarak olumsuz görüşlere sahiptir. Destek teması altında, kadınların gerek iş ortamında gerekse özel yaşamlarında manevi destek görmedikleri ve kadınlar arası çatışmaların yoğun olduğu göz önünde bulundurulduğunda çalışanlar arası empatiyi geliştirmek ve sosyal desteği artırmak için okul içi ve dışı paylaşımların yer alacağı çeşitli aktivitelerin süreci olumlu etkileyebileceği düşünülebilir. Yapı teması altında, bulgular incelendiğinde kadınların birbirlerine yönelik çok sayıda olumsuz kavramlarla yaklaşıldığı görülmüştür. Okul ortamında olumsuzlukları gidermek için öncelikli olarak tecrübeli kadın olmazsa erkek yöneticiler ve öğretmenlerin karşıııklı anlayışı geliştirmek için rehberlik etmesi ve daha yakın çalışma ortamlarının oluşturulması önerilebilir. Yeterlilik temasında ise, kadın yöneticilere olan olumsuz bakışın tecrübe eksikliğinden kaynaklandığı belirtilebilir. Bu doğrultuda sorunların azalmasına yardımcı olabilecek uygulamalar olarak, özellikle kadın yönetici sayısının artırıması için kadın yöneticilere yönelik pozitif ayrımcılığın yapılması ve liderlik eğitimlerinin verilmesi gibi öneriler yapılabilir. Böylece süreç içerisinde kadın çalışan ve yöneticilere kendi benlik yapılarına uygun rol modeller yetiştirilebilir ve eğitim sistemi içerisinde kadın duyarlılı̆̆ ve ilgisi doğrultusunda yeni bir yönetim yaklaşımı oluşturulabilir. Ancak araştırmada kadın çalışanlar ve kadın yöneticiler arasındaki ilişkiler KAS bağlamında ele alınmaya çalışılmışır. Araştırma bulguları KAS yaşayan kadın yöneticilerin niteliklerini kısmen desteklediği görülmektedir. Değinilen görüşlerin bazıları kadın ya da erkek çalışanlar ile erkek yöneticiler arasında da yaşanabilir. Özellikle Bickford (2011), KAS cinsiyet ayrımcılığından temellenen bir önyargı olduğunu belirtmektedir. Hatta kadın yöneticiler ile kadın çalışanlar arasındaki kötü ilişkilerin altında yatan sebep olarak da erkek egemen iş ortamının kadın yöneticiler üzerindeki etkisi olarak vurgulanmaktadır. 


\section{KAYNAKLAR}

Adair, J. (2005). Kış̧ırtıcı liderlik: Büyük liderlerden öğretiler, (Çev.) Ozaner, P. Alteo Yayınları, İstanbul.

Agars, M. D. (2004). Reconsidering the impact of gender stereotypes on the advancement of women in organizations. Psychology of Women Quarterly, 28(2), 103-111.

Annis, B. (1995). Men and women in leadership. Canadian Manager, 20(4), 23-25.

Arslan, i. (2008). Kadınlarla çalışmak çok zor. http://blog.milliyet.com.tr/kadinlarla-calismakcok-zor/Blog/?BlogNo=107969 (Erişim Tarihi: 2016, 8 Mayıs).

Avrupa Komisyonu (2015). Factsheet October 2015: Gender balance on corporate boardsEurope is cracking the glass ceiling. http://ec.europa.eu/justice/genderequality/document/index_en.htm\#gender (Erişim Tarihi: 2016, 2 Mayıs).

Barsh, J., \& Yee, L. (2012). Unlocking the full potential of women at work. http://www.mckinsey.com/business-functions/organization/our-insights/unlocking-thefull-potential-of-women-at-work (Erişim Tarihi: 2016, 9 Mayıs).

Benton, S. (1980). Women administrators for the 1980s: A new breed. Journal of the National Association of Women Deans, Administrators and Counselors, 43(4), 18-23.

Bickford, N. (2011). Queen bees - an evolving species or an office myth?. http://www.ft.com/intl/cms/s/0/9bc76152-f3f9-11e0-b22100144feab49a.htmI\#axzz4AUfjMQWj (Erişim Tarihi: 2016, 15 Mayıs).

Carlson, D., Kacmar, M., \& Whitten, D. (2006). What men think about executive women. Harvard Business Review, 84(9), 28-29.

Catalyst (2015). Women CEOs of the S\&P500. http://www.catalyst.org/knowledge/womenceos-sp-500 (Erişim Tarihi: 2016, 1 Mayıs).

Cohen, P. N., \& Huffman, M. L. (2007). Working for the woman? Female managers and the gender wage gap. American Sociological Review, 72(5), 681-704.

Cortis, R., \& Cassar, V. (2005). Perception of and about women as managers: Investigating job involvement, self-esteem and attitudes. Women in Management Review, 20(3), 149164.

Çelikten, M. (2004). Okul müdürü koltuğundaki kadınlar: Kayseri ili örneği. Sosyal Bilimler Enstitüsü Dergisi, 2, 91-118.

Davey, K. M. (2008). Women's accounts of organisational politics as a gendering process. Gender, Work and Organization, 15(6), 650-671.

Derks, B., Van Laar, C., \& Ellemers, N. (2006). Striving for success in outgroup settings: Effects of contextually emphasizing ingroup dimensions on stigmatized group members' social identity and performance styles. Personality and Social Psychology Bulletin, 32, 576-588. http://dx.doi.org/10.1177/0146167205283336.

Derks, B., Ellemers, N., Laar, C., \& Groot, G. (2011). Do sexist organizational cultures create the Queen Bee?. British Journal of Social Psychology, 50, 519-535.

Derks, B., Laar, C., Ellemers, N., \& Raghoe, G. (2015). Extending the Queen Bee Effect: How Hindustani workers cope with disadvantage by distancing the self from the group. Journal of Social Issues, 71(3), 476-496. 
Derks, B., Laar, C., \& Ellemers, N. (2016). The queen bee phenomenon: Why women leaders distance themselves from junior women. The Leadership Quarterly. http://dx.doi.org/10.1016/j.leaqua.2015.12.007.

Dey, I. (1993). Qualitative data analysis: A user-friendly guide for social scientists. London: Routledge Publications.

Eagly, A. H., \& Karau, S. J. (2002). Role congruity theory of prejudice toward female leaders. Psychological Review, 109, 573-598. http://dx.doi.org/10.1037//0033-295×.109.3.573.

Ellemers, N., Van Den Heuvel, H., De Gilder, D., Maass, A., \& Bonvini, A. (2004). The underrepresentation of women in science: Differential commitment or the Queen Bee syndrome?. British Journal of Social Psychology, 43(3), 315-338.

Ellemers, N. (2014). Women at work: How organizational features impact career development. Work and Organizations, 1(1) 46-54.

Elvira, M. M., \& Cohen, L. E. (2001). Location matters: A cross-level analysis of the effects of organizational sex composition on turnover. Academy of Management Journal, 44(3), 591-605.

Eurostat (2009). Average gross annual earnings in industry and services, by gender. http://ec.europa.eu/eurostat/en/web/products-datasets/-/TPS00175 (Erişim Tarihi: 2016, 8 Mayıs).

Ginn, L. W. (1989). A quick look at the past, present, and future of women in public school administration. Research in Education. (RIE Document Reproduction No. ED3310 498). http://eric.ed.gov/?id=ED310498 (Erişim Tarihi: 2016, 12 Mayıs).

Goldin, C. (2014). A grand gender convergence: Its last chapter. The American Economic Review 104(4), 1091-1119.

Gökakın, Z. Ö. (2000). Doksanlı yılların yeni kahramanları: Türkiye'deki girişimci kadın profili. 8. Ulusal Yönetim ve Organizasyon Kongresi, Nevşehir, s. 110-118.

Greasley, K., \& Ashworth, P. (2007). The Phenomenology of "approach to studying": The University Student's Studies within the Lifework. British Educational Research Journal, $32,819-843$.

Groysberg, B., \& Abrahams, R. (2014). Manage your work, manage your life. Harvard Business Review. https://hbr.org/2014/03/manage-your-work-manage-your-life.

Heilman, M. E. (2001). Description and prescription: How gender stereotypes prevent women's ascent up the organisational ladder. Journal of Social Issues, 57(4), 657.

Herring, C. (2009). Does diversity pay? Race, gender and the business case for diversity. American Sociological Review, 74(2), 208-24.

Joecks, J., Pull, K., \& Vetter, K. (2012). Gender diversity in the boardroom and firm performance: What exactly constitutes a "Critical Mass?". Journal of Business Ethics, 118(1), 61-72.

Johnson, Z., \& Mathur-Helm, B. (2011). Experiences with Queen Bees: A South African study exploring the reluctance of women executives to promote other women in the workplace. South African Journal of Business Management, 42(4), 47-55.

Joy, L., Carter, N. M., Wagner, H. M., \& Narayanan, S. (2007). The bottom line, corporate performance and women's representation on boards. 
http://www.catalyst.org/knowledge/bottom-line-corporate-performance-andwomensrepresentation-boards.

Lang, I. (2010). Targeting inequity: The gender gap in US corporate leadership. Statement made before the joint economic committee. http://www.jec.senate.gov/public/index.cfm?a=Files.Serve\&File_id=90f0aaded9f5-

43e7-8501-46bbd1c69bb8.

Linehan, M., \& Scullion, H. (2008). The development of female global managers: The role of mentoring and networking. Journal of Business Ethics, 83(1), 29-40.

Miles, M. B., \& Huberman, A. M. (1994). Qualitative Data Analysis (2nd edition). Thousand Oaks, CA: Sage Publications.

Milli Eğitim Bakanlığı (2015). Milli Eğitim istatistikleri 2015/2016. http://sgb.meb.gov.tr/meb_iys_dosyalar/2016_03/30044345_meb_istatistikleri_orgun_ egitim_2015_2016.pdf.

Morrison, A. M., \& Von Glinov, M. A. (1990). Women and minorities in management. American Psyehologist, 45, 200-208.

Mukherji, S. (2010). The perception of 'Glass Ceiling' in Indian organizations: An exploratory study. South Asian Journal of Management, January-March, 23-42.

Niederle, M., \& Vesterlund, L. (2007). Do women shy away from competition? Do men compete too much?. The Quarterly Journal of Economics, 122(3), 1067-1101.

Özçelik, B. (2008). Kadın çalışan erkek yönetici tercih ediyor. http://www.kigem.com/kadincalisan-erkek-yonetici-tercih-ediyor.html (Erişim Tarihi: 2016, 25 Mayıs).

Özdemir, M. (2010). Nitel veri analizi: Sosyal bilimlerde yöntembilim sorunsalı üzerine bir çalışma. Eskişehir Osmangazi Üniversitesi Sosyal Bilimler Dergisi, 11(1), 323-343.

Parks-Stamm, E. J., Heilman, M. E., \& Hearns, K. A (2008). Motivated to penalize: Women's strategic rejection of successful women. Personality and Social Psychology Bulletin, 34(2), 237-48.

Prentice, D. A., \& Carranza, E. (2002). What women should be, shouldn't be, are allowed to be, and don't have to be: The contents of prescriptive gender stereotypes. Psychology of Women Quarterly, 26(4), 269-28.

Schein, V. E. (1975). Relationships between sex role stereotypes and requisite management characteristics among female managers. Journal of Applied Psychology, 60(3), 340-344.

Sertkaya, Ö., Onay, M. ve Ekmekçi, R. (2013). Spor örgütlerinde kadın yöneticilere yönelik tutumların belirlenmesi. Pamukkale Journal of Sport Sciences, 4, 1-13.

Strauss, A., \& Corbin, J. (1990). Basics of Qualitative Research: Grounded Theory Procedures and Techniques. New Delhi: SAGE Publications.

Türkiye İstatistik Kurumu (2014). istatistiklerle kadın, 2014. http://www.tuik.gov.tr/Kitap.do?metod=KitapDetay\&KT_ID=11\&KITAP_ID=238.

Wiegand, T. (2015). Helping hand or queen bee? The impact of senior-level women on juniorlevel women within organizations. Bachelor's thesis, Harvard College. https://dash.harvard.edu/bitstream/handle/1/14398528/WIEGAND-SENIORTHESIS2015.pdf?sequence=1 (Erişim Tarihi: 2016, 29 Nisan). 
Yıldırım, A. ve Şimşek, H. (2005). Sosyal Bilimlerde Nitel Araştırma Yöntemleri. Ankara: Seçkin Yayıncilık.

Zel, U. (2002). İ̧̧ arenasında kadın yöneticilerin algılanması ve Kraliçe Arı Sendromu. Amme idaresi Dergisi, 35(2), 39-49.

Zenger, J., \& Folkman, J. (2012). Are women better leaders than men?. Harvard Business Review. https://hbr.org/2012/03/a-study-in-leadership-women-do (Erişim Tarihi: 2016, 26 Mayıs). 


\section{SUMMARY}

In the last quarter of the twenty-first century, although women employees makes up half of the labor, it's known that to have significant problems at the point of participation in the business world (Lang, 2010). Currently, women employees provide earning less than men, negative attitudes continue to women and it's more difficult to reach top management positions for women (Carlson, Kacmar and Whitten, 2006; Eurostat, 2009). However, the women' relationship with other women employees is not fully understood in the business world. In particular, the impact of female managers on other female employees has not been investigated. Glass Ceiling Syndrome (GCS) and Queen Bee Syndrome (QBS) may be accepted as agents that to prevent to rise senior management positions of female employees. According to some studies, women managers, while promoting equality and succeed for women employees, there were identified some signs that to prevent opportunities and to work against success of female employees. Female managers' behaviours may be more masculine in QBS and they may put physical and psychological distance between the other female employees (Derks, Laar ve Ellemers, 2016). In today, there has drawn attention as an imbalance between male-female population rate with male-female employment and senior managers rate in Turkey and the world. The proportion of female employees in managerial positions in the Ministry of Education is indicated as $8 \%$. This situation shows that the representation of women in management positions is very low. The aim of this study is to determine the opinions of public primary female school teachers in the context of the QBS.

A descriptive approach has been investigated in this study. The phenomenological pattern as qualitative research methods was used in the study. The study group was constituted fourteen female teachers who work in public primary schools in the district Altındağ in Ankara province in the 2014-2015 academic year. Datas were collected through interviews. The study group was determined by sampling criteria. In this direction, it has been noted to have at least ten years seniority of teachers.

Firstly, the literature review was conducted for interview form. The datas were obtained using a semi-structured form. Primarily, two managers and two teachers were consulted on the draft form. Then interview form has been prepared in accordance with the opinion of the experts. Finally, two Turkish teachers' views were consulted about form in order to eliminate the sense disorders. The interviews were collected in audio and written records. The datas were analyzed descriptively. In the analysis process, firstly, the datas obtained in writing and audio recording were transferred to the computer as the text. Then, the datas were classified according to their subject similarity.

In the study, the views of female teachers was found to be grouped under three main themes as support, temperament and sufficiency. Under the first theme as support, there was largely negative opinions of female teachers can be transferred. Negative opinions were stated to be experienced in power struggles among female executives and to enter into a race environment. In addition, there was determined that the female managers aren't receive enough support from other managers and their families in the business environment and private life. Also, there have been obtained opinions about female managers can do positive discrimination against female employees. Female managers could empathize understanding of the specific situation of women employess and they could help in solving problems. Under the theme temperament, the female employees have been attributed to the high rate of negative behavior and characteristics about female managers. These include jealousy, envy, capricious, vindictiveness, cruelty, selfishness and gossip. However, some female teachers stated that female managers exhibit an aesthetic approach to the problem and they has the responsibility. Under the last theme sufficiency, according to female employees, female managers were inexperienced, their decisions is at the forefront of sensuality and not to provide authorities. It was also noted that the manager's gender isn't important in the working environment. However, the majority of female teachers added that working with male executives is easier. In addition, the majority of female teachers stated that more than one female manager have negatively affect the business environment.

As a result, it's suggested that, activities should be performed to develop empathy between school employees and to improve social support. To provide guidance to improve mutual understanding from experienced managers and teachers and to establish closer working environment. In particular, making positive discrimination towards female managers to increase the number of female managers and to provide leadership education. 